\title{
Discovering Valuable Growth Opportunities: An Analysis of Equity Alliances with IPO Firms
}

\author{
Jeffrey J. Reuer \\ Krannert School of Management, Purdue University, West Lafayette, Indiana 47907, jreuer@purdue.edu \\ Tony W. Tong \\ Leeds School of Business, University of Colorado, Boulder, Colorado 80309, tony.tong@ colorado.edu
}

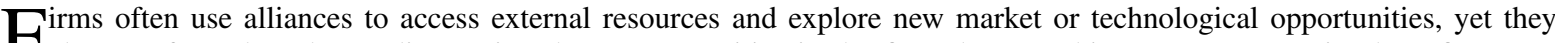

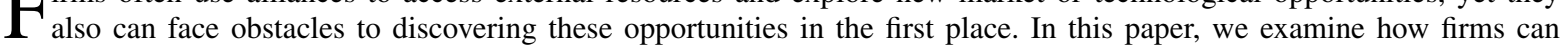
overcome these obstacles and form equity alliances with newly public companies to obtain valuable growth opportunities. Specifically, we build on real options theory and develop the argument that the visibility of firms having an initial public offering (IPO) can shape investors' recognition of the embedded growth opportunities and therefore channel their alliance activities. The evidence shows that firms are more likely to partner with IPO firms possessing more valuable growth opportunities. Furthermore, this relationship is magnified for IPO firms that have obtained more visibility, either through various interorganizational relationships or media coverage on going public.
\end{abstract}

Key words: value of growth options; real options theory; initial public offerings; strategic alliances; search History: Published online in Articles in Advance November 6, 2008.

\section{Introduction}

External partnerships are an important means by which firms can renew their strategies through accessing external key resources and capabilities. Indeed, firms frequently use collaborations to explore new market or technological domains (Koza and Lewin 1998, Rothaermel and Deeds 2004). For instance, Procter and Gamble replaced its "invent it ourselves" approach to innovation with a "connect and develop" model that includes collaborations with various other firms to increase its growth and $R \& D$ productivity (Huston and Sakkab 2006). As a second example, Intel formed a minority equity partnership with Xircom to develop advanced mobile business computing products and obtain better growth prospects outside its maturing core business. As Intel's sales growth in its core business slowed, it expanded its investment in Xircom to boost its wireless offerings.

Although external partnerships may help firms reinvigorate their current strategies by offering new growth opportunities such as these, firms can face nontrivial obstacles in recognizing such opportunities in the first place (e.g., Kogut and Kulatilaka 1994, McGrath 1997, Barnett 2008). To begin with, firms' internal planning and resource-allocation processes can inadvertently foreclose the recognition of new initiatives and growth opportunities (Kogut 1985, McGrath 1999, Bowman and Moskowitz 2001). Without ample sensemaking activities, firms can also fail to discover the "shadow options" they already possess that await recognition (Bowman and Hurry 1993, p. 763). In addition, the spatial and temporal distribution of external opportunities (Hayek 1945) and information uncertainty and search costs (Knight 1921, Stigler 1961) can restrict managerial attention (Bower 1970, Barr et al. 1992) and limit the growth opportunities that firms end up searching for and discovering (e.g., Rangan 2000). It follows that external stimuli shaping firms' attention, or other factors reducing their search costs, will facilitate their discovery of new growth opportunities and channel their alliance activities to these opportunities.

In this paper, we empirically explore these ideas by investigating firms' decisions to engage in equity alliances with newly public companies. Although firms can obtain new growth opportunities in other ways, our analysis focuses on the formation of equity alliances for several reasons. First, scholars studying the process dimensions of managing growth opportunities have devoted much attention to internal development efforts such as resource-allocation processes and corporate venturing (e.g., Bowman and Hurry 1993, McGrath 1997), yet it is also worthwhile to examine such processes in the context of external corporate development activities such as equity alliances. In addition, researchers in this stream have recently examined the challenges surrounding firms' decisions to maintain or abandon growth options following option creation (e.g., Adner and Levinthal 2004, McGrath et al. 2006, Coff and Laverty 2007). Our study moves beyond the existing focus on the staging of follow-on investments to explore the challenges surrounding the initial creation or purchase of growth options in the first place. 
Finally, we focus on equity alliances rather than on other forms of external corporate development because equity alliances represent a particular investment structure that is well suited to the pursuit of growth opportunities. Specifically, equity alliances allow investing firms to avoid large initial sunk costs in the event that the partner's technology or market does not develop favorably, yet investors also hold an option to expand their commitments, if it is in their interests to do so later. In the presence of uncertainty, the investing firm is therefore able to limit its downside losses while positioning itself to capitalize on emerging upside opportunities (e.g., Kogut 1991, Chi 2000, Reuer and Leiblein 2000).

A focus on firms with initial public offerings (IPOs) as alliance partners is also fitting for our purposes, because many of these firms possess valuable growth opportunities because of new technologies and other intangibles, as well as the dynamic industry environments in which they compete (Schwartz and Moon 2000, Chung et al. 2005). More importantly for our theory, IPO firms will differ in the visibility they achieve when going public, and we suggest that this heterogeneity has an impact on investors' abilities to locate them as partners. As such, we not only predict that IPO firms with more valuable growth opportunities are more likely to attract equity alliance partners, but we also expect that this relationship will be magnified by the visibility of the IPO firm.

Our study of equity alliances with IPO firms also contributes to the strategic alliance literature in two ways. Previous research has investigated how pre-IPO business collaborations shape IPO performance (e.g., Stuart et al. 1999, Gulati and Higgins 2003, Chang 2004), and our analysis complements this work by showing how the going-public event can also impact firms' subsequent alliance activities. It is also noted that prior studies commonly take the identity of alliance partners as given for analytical convenience (for exceptions, see Gulati and Gargiulo 1999, Hitt et al. 2004, Ring et al. 2005), and our theory and analyses focus on the means by which firms locate alliance partners with valuable growth opportunities in the first place.

\section{Theory and Hypotheses}

\section{Equity Alliances and the Value of Growth Options}

Although our theoretical development emphasizes the mechanisms that can facilitate firms' recognition of external growth opportunities and potential alliance partners, we begin with the observation that some newly public firms are intrinsically more attractive as alliance partners. In fact, a substantial body of research has been devoted to the question of why firms pursue equity alliances or other forms of interfirm collaboration. Firms' diverse motives for alliances include obtaining access to knowledge or other resources (Hagedoorn 1993, Inkpen and Beamish 1997, Dyer and Singh 1998,
Robins et al. 2002), facilitating entry into new markets (Mitchell and Singh 1992, Balakrishnan and Koza 1993, Barkema et al. 1997), learning from partners (Mowery et al. 1996, Dussauge et al. 2000, Dhanaraj et al. 2004), building trust and managing exchange hazards to achieve mutual benefits (Parkhe 1993, Ariño and de la Torre 1998), and so forth.

Given our focus on firms' exploration for growth opportunities in uncertain markets, we rely on real options analysis to derive a baseline prediction that links the formation of equity alliances to the partner firm's growth option value. Growth options refer to the future growth opportunities of a firm, which often arise from its uncertain real investments (Myers 1977, Kester 1984, Pindyck 1988). In particular, growth option value is the proportion of firm value that can be attributable to future growth opportunities rather than assets in place (Myers 1977, Kester 1984, Brealey and Myers 2000). Previous research on real options theory has suggested that growth option value varies widely across firms and that it is also tied to the uncertainty of the environment in which firms operate (Kester 1984, Pindyck 1988, Long et al. 2005, Tong and Reuer 2006, Tong et al. 2008).

Kogut (1991) provides the first set of theoretical arguments and empirical evidence that firms use equity alliances as a means of obtaining growth options. The core of this argument is that a firm is able to reduce downside losses by making a limited initial investment via an equity alliance, yet it holds a growth option and can position itself to expand through the acquisition of additional equity, if future circumstances turn out favorably. The study focuses on the exercise, rather than the initial purchase, of the growth option; the findings show that a firm expands by buying out its partner's ownership stake when a positive demand shock materializes, but the firm holds this option open if negative market signals are present. Analytical and empirical research that has followed firms' decisions to purchase or create growth options as well as to exercise growth options, such as by forming and terminating equity alliances under conditions of uncertainty (e.g., Chi and McGuire 1996, Chi 2000, Folta 1998, Folta and Miller 2002). However, no research to date has directly investigated the relationship between the formation of equity alliances and the partner firm's growth option value. We seek to address this gap and suggest that IPO firms will differ in their growth option values and that those possessing higher growth option values are more likely to attract equity alliance partners. Therefore:

HyPOTHESIS 1. The greater the IPO firm's growth option value, the greater the likelihood that an investor will invest in an equity alliance with the IPO firm.

\section{Recognition of Valuable Growth Options}

It is one thing for some IPO firms to possess valuable growth options and thus be intrinsically attractive 
as partners for equity alliances; it is quite another for other firms to be able to locate these partners efficiently. Indeed, if firms routinely encounter difficulties in perceiving embedded "shadow" options internal to the firm (Bowman and Hurry 1993), it will be all the more challenging for them to recognize external growth options. Some growth options might be easier to recognize inasmuch as they are shared among industry participants (Kester 1984, Trigeorgis 1996), yet many valuable growth options are associated with firm-specific investments in R\&D, capital expenditures, etc., and are harder to identify (Myers 1977, Kogut and Kulatilaka 1994, McGrath and Nerkar 2004). In existing applications of real options theory to equity alliances, however, firms are often depicted as having already identified the partner with whom they wish to collaborate or invest further, so the focal decision centers on a deal-structuring choice that takes the exchange partner as given. However, new opportunities for exchange often emerge, firms enter and exit industries, and other internal and external conditions can change (e.g., Stigler 1961). All of this can stimulate search by firms as well as lead to serendipitous discoveries of opportunities for alliances.

The process of locating new growth options externally will therefore be subject to various challenges that must be addressed to understand the obstacles firms face in identifying potential partnerships and accessing external growth options. Such growth options are often dispersed in space and time (e.g., Hayek 1945), and they are often difficult for managers to perceive and evaluate (Busby and Pitts 1997, Howell and Jagle 1997). Whereas traders of financial options enjoy certain institutional arrangements, such as liquid markets and public postings of offerings that reduce transaction costs, buyers and sellers of real options often find themselves separated by geographic, product-market, or other technical barriers (Lander and Pinches 1998, Amram and Kulatilaka 1999). Under these conditions, firms may incur significant search costs (Rangan 2000), as they need to scan for sellers or buyers, encode and decode signals, and employ intermediaries or other agents in the process (Arrow 1974).

Our central proposition, therefore, is that the formation of equity alliances with IPO firms will depend not only on the value of their growth options, but will also be conditioned by the degree to which such firms are visible to prospective partners. Given the frictions caused by search costs and bounded rationality, we propose that the visibility of an IPO firm will positively moderate the relationship between its growth option value and the likelihood that an investor will form an equity alliance with it. IPOs in general produce a substantial amount of information on a firm through registrations, road shows, prospectuses, public listing, and so forth (Blowers et al. 1999), and research indicates that firms indeed often go public precisely to enhance their visibility (Ravasi and Marchisio 2003, Brau and Fawcett 2006). Recent evidence also suggests that the information generated during the IPO process affects the behavior of firms and customers in other market contexts such as merger and acquisition and product markets (Field and Karpoff 2002, Demers and Lewellen 2003).

In the development of the hypotheses that follow, we suggest that visibility varies across IPO firms and that IPO firms can obtain visibility in different ways. Specifically, our theory development considers two different means by which IPO firms may become more visible: First, alliance investors can become aware of the IPO firm through the direct and indirect effects of the firm's interorganizational relationships. For example, as we discuss below, the IPO firm's pre-IPO alliances, or its association with a prominent investment bank, are likely to enhance its visibility, which in turn can enlarge the set of potential investors interested in forming an equity alliance with the firm. Second, information on the IPO firm might also be conveyed to a broad range of prospective collaborators through more diffuse means, such as the media. In both cases, enhanced visibility of the IPO firm can facilitate alliance investors' search and discovery of new growth opportunities and thereby increase the likelihood that they will invest in an equity alliance with the IPO firm.

Pre-IPO Alliances. One of the chief means through which an IPO firm can become visible is collaborative relationships leading up to its IPO. Research has argued that prior alliances and linkages offer both direct and indirect benefits that can facilitate organizational exchanges under uncertainty in general, and we extend this logic to firms' exchanges in growth options in particular. For instance, research on interorganizational linkages argues that prior alliances help firms access information and uncover latent opportunities (Gulati 1995). More generally, Rangan (2000) develops the theory that interfirm alliances will be useful in facilitating transactions when organized markets or other institutions are not available to send or receive supply-demand signals cost effectively. One implication of his model is that prior alliances offer the benefit of enlarging a firm's set of potential exchange partners in the future.

Alliances can also generate information and affect prospective investors' attention through the signals they convey to unaffiliated firms. For example, alliances are often associated with value creation (e.g., Koh and Venkatraman 1991) as well as enhanced growth opportunities and survival prospects (e.g., Mitchell and Singh 1996, Singh and Mitchell 2005), so other firms may presume that a firm engaged in these collaborative agreements possesses valuable growth opportunities. Related research has presented evidence that alliances can enhance a firm's visibility among a broad range of unaffiliated organizations and enlarge its set of prospective investors. Jensen (2004), for instance, argues that 
alliances can help the firm draw more research coverage by stock analysts. Along similar lines, Stuart et al. (1999) suggest that strategic alliances can help young companies attract financial and other resources. To the extent that alliances can enhance a firm's visibility through these direct or indirect means, we offer the following prediction:

HYPOTHESIS 2. The greater the number of the IPO firm's pre-IPO alliances, the greater the positive relationship between the firm's growth option value and the likelihood that an investor will invest in an equity alliance with the firm.

Underwriter Prominence. An IPO firm's association with its investment bank represents another type of interfirm relationship that is likely to have an important effect on the visibility of the firm. Such associations can shape the IPO firm's visibility in several ways, yet several parallels exist to the discussion above. To begin with, the most prominent investment banks also have extensive networks with other organizations and are actively engaged in advisory services (Kesner et al. 1994). For example, Ravasi and Marchisio's (2003) survey of Italian IPOs reports that the process of going public helps introduce the IPO firm to a "restricted industrial elite, with privileged relationships within the financial community" (p. 389). Their evidence suggests that enhancing the visibility of the firm is one of the most important motives for Italian IPOs. Brau and Fawcett's (2006) survey of CFOs of IPO firms indicates that acquisition posturing is the most common motive for going public and that the reputation of investment banks underwriting IPOs might play a role in the process. Other research in finance also suggests that associations with prominent underwriters can enhance the firm's visibility and generate positive signals on the firm's future prospects. For example, IPO firms are more willing to use the services of prominent investment banks because of the additional future benefits the banks can offer, such as research coverage, investment exposure, subsequent equity offerings, and so forth (e.g., Titman and Trueman 1986, Demers and Lewellen 2003, Loughran and Ritter 2004). To the extent that associations with prominent investment banks increase visibility for the IPO firm, we predict the following:

HYPOTHESIS 3. The greater the prominence of the IPO firm's investment bank, the greater the positive relationship between the firm's growth option value and the likelihood that an investor will invest in an equity alliance with the firm.

Media Coverage. The above two hypotheses emphasize the visibility that newly public firms can attain through different interfirm relationships. However, knowledge about the IPO firm can also reach out to other firms from a broad range of industries or geographic markets (e.g., Casella and Hanaki 2006) through more diffuse, public channels, such as the media. Such broadbased exposure might be related to other sources of visibility discussed above, but it is conceptually distinct. Consideration of the media therefore provides for a more complete theoretical framework and set of conditions that affect the IPO firm's visibility.

Recent research in financial economics and management has begun to emphasize the importance of the media in the IPO setting, and we wish to connect the insights of this work to post-IPO investment activities such as equity alliances. In particular, this research has shown that the exposure the IPO firm receives in the media on going public can have far-reaching consequences for its performance as well as its activities in different market contexts. For example, Demers and Lewellen (2003) draw on arguments from marketing and the economics of information to study the promotional benefits of IPOs. They present evidence that media exposure for Internet IPOs translates into increased Web traffic, suggesting that the information generated through IPOs spills over into the product market and has an influence on customers' behavior. Pollock and Rindova (2003) also argue that the media work to enhance familiarity and public knowledge of the IPO firm, thereby facilitating the workings of capital markets. To the extent that media coverage can enhance a firm's visibility and increase the efficiency of other markets, we posit that the media can also facilitate the functioning of the market for alliance partners, thus:

HYPOTHESIS 4. The greater the number of media mentions the IPO firm receives surrounding its IPO, the greater the positive relationship between the firm's growth option value and the likelihood that an investor will invest in an equity alliance with the firm.

\section{Data and Methods}

\section{Sample and Data}

Thompson Financial's Security Data Corporation (SDC) database provides the base sample of IPO firms used in this study. The SDC database offers detailed data on firms' IPO, alliance, and merger and acquisition activities, and given the comprehensiveness of its coverage, the database has been used widely in prior research in management and other fields. We first obtained from SDC all IPOs of common shares by U.S. firms from 1991-1998; we ended in 1998 to avoid effects associated with the stock market bubble in 1999 and 2000. We also followed previous IPO research and excluded transactions involving real estate investment trusts, closed-end funds, equity carve-outs involving units of diversified firms, leverage buyouts, and offering by firms operating in the financial services sector. We then merged this information with other data from SDC to determine whether and when an IPO firm became the object of an 
equity alliance. Finally, we matched the IPO firms with their accounting and financial information available from the Compustat database and the Center for Research in Security Prices (CRSP) data files. These efforts resulted in 1,107 IPO firms with complete data, which comprised our final sample. Of these firms, $278(25 \%)$ received a minority investment; an additional 367 were subject to an acquisition in which the acquirer purchased at least $50 \%$ of the target's equity; 15 were delisted; and 447 were still operating independently at the end of the sample period.

We focused on minority investments as a form of equity alliance; this is consistent with previous research on alliances as well as the real options literature (Pisano 1989, Folta and Miller 2002). In our specific context, such equity alliances are investments made in an IPO firm seeking an equity position of less than 50\%.

Focusing on minority investments rather than other alliances that might also provide access to growth options is attractive to us for two other reasons. First, such equity alliances involve a clear direction of investment, unlike joint ventures. The directionality of investment is important for us because it can better capture our theoretical argument and empirical focus on investors' discovery and pursuit of new growth opportunities possessed by the IPO firm. Second, minority investments involve a partial ownership claim on the IPO firm as a whole, so such investments can be better connected to the IPO firm's growth option value because both constructs operate at the same firm level of analysis. By contrast, other equity alliances such as joint ventures are often used by firms to access resources situated in particular business units or parts of the partner, rather than the partner firm as a whole (e.g., Hennart and Reddy 1997).

\section{Statistical Model}

We used hazard models to test the hypotheses developed above. Hazard models are specifically designed for studying longitudinal data on the occurrence and timing of events such as those contained in our data set. In particular, hazard models offer several advantages over other methods, such as the ability to utilize information on the exact timing of the event and to treat nonevents as right censored, thus increasing the precision of the estimates and reducing estimation biases (see Allison 1995, pp. 2-5). Specifically, we employed Cox's (1972) proportional hazard model to test our hypotheses. Research has shown that coefficient estimates provided by the Cox model are consistent and robust, and they are asymptotically normal and allow for ease of interpretation (see Cox and Oakes 1984 for a more detailed explanation). The dependent variable in the model is a hazard rate that indicates the likelihood that an IPO firm will become the object of an equity alliance. Cox's hazard model estimates the influence of independent variables on the hazard of the equity alliance event; specifically, the model assumes that the hazard rate for firm $j, h\left(t \mid \mathbf{x}_{j}\right)$, is a function of the independent variables $\mathbf{x}_{j}$ and is written as:

$$
h\left(t \mid \mathbf{x}_{j}\right)=h_{0}(t) \exp \left(\mathbf{x}_{j} \boldsymbol{\beta}_{x}\right),
$$

where $\boldsymbol{\beta}_{x}$ is a vector of coefficients to be estimated. The hazard function $h\left(t \mid \mathbf{x}_{j}\right)$ consists of two parts. The first part, $h_{0}(t)$, is the baseline hazard, and it is obtained by setting $\mathbf{x}$ equal to zero so that the baseline hazard for firm $j$ corresponds to the hazard rate with $\mathbf{x}_{j}$ set to zero. The Cox model is a semiparametric model in that $\boldsymbol{\beta}_{x}$ is estimated without specifying a parametric form for the time to failure, therefore making no assumptions about the nature or shape of the hazard function. The second part, $\exp \left(\mathbf{x}_{j} \boldsymbol{\beta}_{x}\right)$, called the relative hazard, is a function of a vector of explanatory variables. The model is proportional in that the hazard is obtained by shifting the baseline hazard as the explanatory variables change. The model assumes that, whatever the shape of the baseline hazard, it is the same for all firms; therefore, the baseline hazard cancels out, and there are no intercepts. In the results reported below, we used the robust standard errors proposed by Lin and Wei (1989).

\section{Theoretical Variables}

Dependent Variable. Our dependent variable, Equity Alliance, denotes whether the IPO firm became the object of an equity alliance. We collected data on the date the firm went public and the date the first minority equity investment was made in the firm, if such a partnership was formed. Firms that were still operating independently without an equity partnership at the end of the sample period were treated as right censored. Hazard models also allowed us to incorporate competing risks by treating other events such as outright acquisitions or delistings as distinct risks (see Cox and Oakes 1984). We followed Allison (1995, pp. 185-209) and entered these other events into the competing risk set and calculated the time to these other events, so there was no loss of timing information.

Growth Option Value. Our main theoretical variable is Growth Option Value, defined as the proportion of the firm's value that is attributable to growth options. The variable has significant precedent in the finance literature and has been used in recent applications of real options theory in the strategy field. Its theoretical origins can be traced to Myers (1977), who first coined the term "growth options" to indicate a firm's discretionary future growth opportunities. Myers' (1977) seminal ideas provide a useful perspective to understand the theory of corporate valuation, allowing researchers to estimate a firm's growth option value. Specifically, his work extends the valuation theory formalized by Miller and Modigliani (1961) and partitions the value of the 
firm $(\mathrm{V})$ into the value of assets in place $\left(\mathrm{V}_{\mathrm{AIP}}\right)$ and the value of growth options $\left(\mathrm{V}_{\mathrm{GO}}\right)$ :

$$
\mathrm{V}=\mathrm{V}_{\mathrm{AIP}}+\mathrm{V}_{\mathrm{GO}} \text {. }
$$

Kester (1984) is among the first to empirically estimate growth option value. Specifically, he measures the firm's value of growth options $\left(\mathrm{V}_{\mathrm{GO}}\right)$ as the difference between its market value $(\mathrm{V})$ and the capitalized value of its current earnings, which represents the value of assets in place $\left(\mathrm{V}_{\mathrm{AIP}}\right)$. He then calculates a firm's growth option value $(\mathrm{GOV})$ as the value of growth options $\left(\mathrm{V}_{\mathrm{GO}}\right)$, stated as a percentage of the firm's market value $(\mathrm{V})$ :

$$
\begin{aligned}
\mathrm{GOV} & =\mathrm{V}_{\mathrm{GO}} / \mathrm{V}=\left(\mathrm{V}-\mathrm{V}_{\mathrm{AIP}}\right) / \mathrm{V} \\
& =[\mathrm{V}-\text { Current Earnings } / \text { Discount Rate }] / \mathrm{V} .
\end{aligned}
$$

Current earnings and the value of the firm are readily obtained, and Kester (1984) applies a discount rate of $20 \%$ to discount a perpetuity of current earnings to calculate the value of assets in place $\left(\mathrm{V}_{\mathrm{AIP}}\right)$. Kester also uses two other discount rates (i.e., 15 and $25 \%$ ) for this purpose, and he finds that using these discount rates, many firms have growth option values higher than $50 \%$ and as high as around 90\%. Kester's (1984) approach is consistent with Myers' (1977) initial conceptualization of growth options, and related work has adopted a similar approach to calculating growth option values (e.g., Stewart 1991, Brealey and Myers 2000, Long et al. 2005, Tong and Reuer 2006, Alessandri et al. 2007). Because the measure of growth option value relies on financial market data, it can only be determined for firms that are publicly traded rather than privately held. Moreover, because growth option value is a residual measure using both financial and accounting information, it can take on values that are either negative or greater than one, depending on a firm's investments in future growth opportunities and its current profitability. In particular, many IPO firms' market values derive predominantly from growth options, even when they have negative current earnings (e.g., Schwartz and Moon 2000, Loughran and Ritter 2004).

We followed Kester (1984) to estimate the IPO firm's growth option value. Specifically, we measured the firm's value (V) as the market value of its common stock plus the book value of its preferred stock as well as its debt. We then applied $20 \%$ to capitalize the firm's current earnings to obtain its value of assets in place $\left(\mathrm{V}_{\mathrm{AIP}}\right)$. Finally, the firm's growth option value was calculated using Equation (3). According to the calculation, it was evident that all of the three discount rates that Kester uses would provide growth option value estimates that are perfectly correlated to one another; hence, our results (presented below) do not depend on the use of a particular discount rate. Compustat and CRSP provided the data sources for this measure.
Pre-IPO Alliances. To test Hypothesis 2, we were interested in whether the interaction between a firm's number of pre-IPO alliances and its growth option value would affect the likelihood of equity alliances following the IPO. It is also useful to control for the direct effect of pre-IPO alliances, because firms that have engaged in alliances in the past are more likely to be involved in them again, whether from collaborative capabilities or momentum. To measure the firm's number of pre-IPO alliances, we used SDC to count the number of alliances the firm had previously formed. We then defined the variable Pre-IPO Alliances as the log of one plus the number of alliances, to remedy positive skewness that was evident for the pretransformed count measure, which can inflate the risks of Type I and Type II errors (Tabachnick and Fidell 1996). We used one plus the number of alliances in the transformation because some firms had no prior alliances and the log of zero is undefined.

Investment Bank Reputation. The second variable used to interact with growth option value is the prominence of the investment bank that took a firm public. We measured Investment Bank Reputation using the ranking index first developed by Carter and Manaster (1990). The index is constructed according to the positions that investment banks occupy in "tombstone" announcements that list members of the underwriting syndicate; this index has been used widely in prior research in finance, strategy, and other fields (e.g., Stuart et al. 1999; Gulati and Higgins 2003; Higgins and Gulati 2003, 2006). For banks that always appear in the highest bracket, a ranking of nine is assigned, whereas investment banks receive lower rankings should their position in successive tombstone announcements drop. Given that IPOs are most often comanaged by underwriting syndicates formed by multiple investment banks, we followed previous studies and focused on the reputation index of the IPO's lead underwriter. We used the data on investment bank reputation from Loughran and Ritter (2004), as it utilizes expert knowledge for exceptional cases, covers a long period of time, and updates prior data sources.

Media Coverage. The third interaction variable is the coverage that an IPO firm receives in the media, and it is a proxy for the level of publicity during the IPO process. We followed previous research (e.g., Demers and Lewellen 2003, Pollock and Rindova 2003) and measured Media Coverage as the number of media mentions by searching through newspapers and articles available about the IPO firm in the major newspaper and other databases of Lexis-Nexis. Following Demers and Lewellen (2003), we examined the IPO firm's media mentions beginning from two months before the IPO to two months after. However, we found that counts of media mentions of different time windows were very highly correlated to one another $(r>0.96, p<0.001)$, 
as was also shown in Demers and Lewellen (2003). In addition, regression results were qualitatively similar regardless of the different time windows used to generate the counts. To account for substantial skewness in the data, we used a log transformation and added one to all observations before taking the logarithm, as before.

\section{Control Variables}

We incorporated a number of control variables in the analyses. The first set of controls is comprised of six variables related to the IPO firm. We first controlled for Firm Size, which was measured as the natural log of the IPO firm's total assets in millions of dollars. Second, we included a control for Firm Growth, measured as the firm's annual sales growth rate in the consecutive years prior to an IPO. This variable captures the firm's historical growth and other effects related to growth that may influence the likelihood of equity alliances in the post-IPO period (Field and Karpoff 2002). Third, we also controlled for the effects of Liquidity. We followed Field and Karpoff (2002) and measured this variable as the ratio of net liquid assets (current assets minus current liabilities) to total assets. Data for the three variables were obtained from Compustat. The other three firm-level control variables are features associated with the IPO process. We included a dummy variable $V C$ Backing to indicate whether an IPO firm was backed by a venture capitalist at the time it went public (e.g., Megginson and Weiss 1991). We next controlled for IPO Underpricing, or the IPO firm's first-day stock returns, as underpricing can reflect uncertainty about the firm and can also be a mechanism by which firms can convey signals about their prospects (e.g., Allen and Faulhaber 1989). IPO underpricing was measured as the percentage change between the price at the close of trading on the first day and the IPO's offer price. Finally, we also controlled for the stock market on which the shares of the issuer were listed. A firm's stock market choice is an important decision related to the IPO, and the desire for visibility, prestige, and access to investors can influence this decision. Researchers and practitioners have suggested that the NASDAQ market in particular can contribute to firms' visibility because of its unique market making feature, and it also imparts an image of high growth and technological advancement (Blowers et al. 1999, Corwin and Harris 2001). We thus incorporated a dummy variable NASDAQ Exchange to indicate whether a firm was listed on the NASDAQ market. Data for these three variables were obtained from SDC and CRSP.

We also sought to control for industry-level heterogeneity and the broader environment of firms going public. We included a dummy variable High-Tech Industry to distinguish high-tech and other IPO firms, because high-tech firms tend to be active in the IPO market as well as the alliance setting. We used AeA's industry definitions to identify 45, four-digit-level Standard Industrial Classification codes making up high-tech industries. $\mathrm{AeA}$ is the nation's largest high-tech trade association and classifies industries as high-tech if this portion of their activities constitutes the majority of their businesses. Alternatively, we included a series of industry fixed effects, and we obtained results similar to those reported below. Finally, we also controlled for Year Fixed Effects, denoting the year of IPO to account for effects caused by economy-wide factors.

\section{Results}

Table 1 presents descriptive statistics and a correlation matrix of the variables used in the analyses. Given the focus on newly public firms, the average growth option value appears higher than in other analyses involving established firms (e.g., Chung et al. 2005, Long et al. 2005, Tong and Reuer 2006, Alessandri et al. 2007). The average IPO firm in our sample had 1.45 preIPO alliances and received 7.85 mentions in the media. Thirty-five percent of the IPO firms received funding from venture capitalists, $70 \%$ of them listed their stocks on the NASDAQ exchange, and $28 \%$ of them

Table 1 Descriptive Statistics and Correlation Matrix

\begin{tabular}{|c|c|c|c|c|c|c|c|c|c|c|c|c|c|}
\hline Variable & Mean & S.D. & (1) & (2) & (3) & (4) & (5) & (6) & (7) & (8) & (9) & (10) & (11) \\
\hline 1. Equity alliance & 0.25 & 0.43 & & & & & & & & & & & \\
\hline 2. Growth option value & 0.93 & 0.44 & $0.12^{* * *}$ & & & & & & & & & & \\
\hline 3. Pre-IPO alliances & 0.37 & 0.61 & $0.19^{* * *}$ & $0.25^{* * * *}$ & & & & & & & & & \\
\hline $\begin{array}{l}\text { 4. Investment bank } \\
\text { reputation }\end{array}$ & 6.84 & 2.46 & $0.05^{\dagger}$ & $-0.05^{\dagger}$ & $0.22^{* * *}$ & & & & & & & & \\
\hline 5. Media coverage & 2.06 & 1.10 & 0.03 & $-0.06^{\dagger}$ & $0.19^{* * * *}$ & $0.31^{* * *}$ & & & & & & & \\
\hline 6. Firm size & 4.04 & 1.38 & -0.01 & $-0.41^{* * * *}$ & $0.06^{\dagger}$ & $0.69^{* * *}$ & $0.36^{* * *}$ & & & & & & \\
\hline 7. Firm growth & 2.28 & 19.71 & 0.01 & $0.06^{\dagger}$ & 0.02 & 0.01 & 0.03 & 0.02 & & & & & \\
\hline 8. Liquidity & 0.42 & 0.30 & $0.07^{*}$ & $0.33^{* * *}$ & $0.33^{* * *}$ & $-0.06^{*}$ & -0.02 & $-0.37^{* * *}$ & -0.01 & & & & \\
\hline $\begin{array}{l}\text { 9. Venture capitalist } \\
\text { backing }\end{array}$ & 0.35 & 0.48 & $0.16^{* * *}$ & $0.28^{* * *}$ & $0.34^{* * *}$ & $0.23^{* * *}$ & $0.08^{*}$ & -0.04 & 0.01 & $0.27^{* * *}$ & & & \\
\hline 10. IPO underpricing & 0.15 & 0.28 & $-0.05^{\dagger}$ & $0.07^{*}$ & $0.07^{*}$ & 0.02 & $0.19^{* * *}$ & -0.01 & 0.04 & $0.15^{* * *}$ & -0.02 & & \\
\hline 11. NASDAQ exchange & 0.70 & 0.46 & -0.02 & -0.04 & $0.12^{* * *}$ & $0.27^{* * *}$ & $0.08^{* *}$ & $0.06^{\dagger}$ & 0.04 & $0.18^{* * *}$ & $0.21^{* * *}$ & $0.07^{*}$ & \\
\hline 12. High-tech industry & 0.28 & 0.45 & -0.02 & $0.15^{* * *}$ & $0.20^{* * *}$ & $0.09^{* *}$ & $0.06^{*}$ & -0.03 & 0.01 & $0.21^{* * *}$ & $0.16^{* * *}$ & $0.23^{* * *}$ & $0.14^{* * *}$ \\
\hline
\end{tabular}

Notes. $N=1,107 ;{ }^{\dagger} p<0.10 ;{ }^{*} p<0.05,{ }^{* *} p<0.01,{ }^{* * *} p<0.001$. 
Table 2 Cox Regression Results

\begin{tabular}{|c|c|c|c|c|c|c|}
\hline \multirow[b]{2}{*}{ Independent variables } & \multicolumn{6}{|c|}{ Models } \\
\hline & I & II & III & IV & V & $\mathrm{VI}$ \\
\hline Firm size & $\begin{array}{c}0.07 \\
(0.05)\end{array}$ & $\begin{array}{c}0.07 \\
(0.07)\end{array}$ & $\begin{array}{c}0.08 \\
(0.07)\end{array}$ & $\begin{array}{c}0.10 \\
(0.07)\end{array}$ & $\begin{array}{c}0.08 \\
(0.07)\end{array}$ & $\begin{array}{c}0.12 \\
(0.08)\end{array}$ \\
\hline Firm growth $\left(\times 10^{-2}\right)$ & $\begin{array}{c}0.23 \\
(0.25)\end{array}$ & $\begin{array}{c}0.15 \\
(0.27)\end{array}$ & $\begin{array}{c}0.19 \\
(0.26)\end{array}$ & $\begin{array}{c}0.12 \\
(0.28)\end{array}$ & $\begin{array}{c}0.13 \\
(0.28)\end{array}$ & $\begin{array}{c}0.14 \\
(0.28)\end{array}$ \\
\hline Liquidity & $\begin{array}{r}0.39^{\dagger} \\
(0.24)\end{array}$ & $\begin{array}{c}-0.11 \\
(0.25)\end{array}$ & $\begin{array}{c}-0.11 \\
(0.25)\end{array}$ & $\begin{array}{c}-0.24 \\
(0.25)\end{array}$ & $\begin{array}{c}-0.11 \\
(0.25)\end{array}$ & $\begin{array}{c}-0.21 \\
(0.26)\end{array}$ \\
\hline Venture capitalist backing & $\begin{array}{c}0.56^{* * *} \\
(0.13)\end{array}$ & $\begin{array}{c}0.29^{*} \\
(0.14)\end{array}$ & $\begin{array}{r}0.25^{\dagger} \\
(0.15)\end{array}$ & $\begin{array}{r}0.26^{\dagger} \\
(0.15)\end{array}$ & $\begin{array}{r}0.26^{\dagger} \\
(0.15)\end{array}$ & $\begin{array}{c}0.23 \\
(0.15)\end{array}$ \\
\hline IPO underpricing & $\begin{array}{c}-0.28 \\
(0.30)\end{array}$ & $\begin{array}{r}-0.30 \\
(0.29)\end{array}$ & $\begin{array}{c}-0.25 \\
(0.29)\end{array}$ & $\begin{array}{r}-0.24 \\
(0.29)\end{array}$ & $\begin{array}{c}-0.30 \\
(0.29)\end{array}$ & $\begin{array}{c}-0.25 \\
(0.29)\end{array}$ \\
\hline NASDAQ exchange & $\begin{array}{c}-0.19 \\
(0.13)\end{array}$ & $\begin{array}{c}-0.18 \\
(0.14)\end{array}$ & $\begin{array}{c}-0.21 \\
(0.14)\end{array}$ & $\begin{array}{r}-0.28^{\dagger} \\
(0.15)\end{array}$ & $\begin{array}{c}-0.22 \\
(0.14)\end{array}$ & $\begin{array}{r}-0.26^{\dagger} \\
(0.14)\end{array}$ \\
\hline High-tech industry & $\begin{array}{c}0.05 \\
(0.15)\end{array}$ & $\begin{array}{c}-0.01 \\
(0.15)\end{array}$ & $\begin{array}{c}0.07 \\
(0.15)\end{array}$ & $\begin{array}{c}0.04 \\
(0.15)\end{array}$ & $\begin{array}{c}-0.02 \\
(0.15)\end{array}$ & $\begin{array}{c}0.09 \\
(0.15)\end{array}$ \\
\hline Year fixed effects & $21.68^{* *}$ & $23.87^{* *}$ & $23.70^{* *}$ & $27.91^{* * *}$ & $25.33^{* * *}$ & $28.26^{* * *}$ \\
\hline Growth option value (GOV) & & $\begin{array}{l}0.62^{* * *} \\
(0.15)\end{array}$ & $\begin{array}{l}0.54^{* * *} \\
(0.16)\end{array}$ & $\begin{array}{l}0.82^{* * * *} \\
(0.17)\end{array}$ & $\begin{array}{l}0.71^{* * * *} \\
(0.16)\end{array}$ & $\begin{array}{l}0.80^{* * *} \\
(0.18)\end{array}$ \\
\hline Pre-IPO alliances & & $\begin{array}{l}0.34^{* * * *} \\
(0.10)\end{array}$ & $\begin{array}{l}0.34^{* * *} \\
(0.10)\end{array}$ & $\begin{array}{c}0.31^{* *} \\
(0.10)\end{array}$ & $\begin{array}{l}0.35^{* * * *} \\
(0.10)\end{array}$ & $\begin{array}{l}0.32^{* *} \\
(0.10)\end{array}$ \\
\hline Investment bank (IB) reputation & & $\begin{array}{c}0.03 \\
(0.04)\end{array}$ & $\begin{array}{c}0.02 \\
(0.04)\end{array}$ & $\begin{array}{c}0.03 \\
(0.04)\end{array}$ & $\begin{array}{c}0.03 \\
(0.04)\end{array}$ & $\begin{array}{c}0.02 \\
(0.04)\end{array}$ \\
\hline Media coverage & & $\begin{array}{c}0.02 \\
(0.06)\end{array}$ & $\begin{array}{c}0.03 \\
(0.06)\end{array}$ & $\begin{array}{c}0.01 \\
(0.06)\end{array}$ & $\begin{array}{c}0.06 \\
(0.06)\end{array}$ & $\begin{array}{c}0.05 \\
(0.06)\end{array}$ \\
\hline GOV $*$ pre-IPO alliances & & & $\begin{array}{l}0.59^{* *} \\
(0.21)\end{array}$ & & & $\begin{array}{c}0.43^{*} \\
(0.22)\end{array}$ \\
\hline GOV $*$ IB reputation & & & & $\begin{array}{l}0.18^{* * * *} \\
(0.06)\end{array}$ & & $\begin{array}{l}0.14^{* *} \\
(0.05)\end{array}$ \\
\hline GOV $*$ media coverage & & & & & $\begin{array}{l}0.38^{* *} \\
(0.14)\end{array}$ & $\begin{array}{c}0.27^{*} \\
(0.14)\end{array}$ \\
\hline $\begin{array}{l}\chi^{2} \\
\text { Log likelihood, } L(\beta) \\
-2\left[L\left(\beta_{\text {baseline }}\right)-L\left(\beta_{i}\right)\right] \sim \chi^{2}\end{array}$ & $\begin{array}{c}56.68^{* * *} \\
-1,816.54\end{array}$ & $\begin{array}{l}90.52^{* * *} \\
-1,799.62 \\
33.84^{* * *}\end{array}$ & $\begin{array}{c}98.34^{* * *} \\
-1,795.71 \\
7.82^{* *}\end{array}$ & $\begin{array}{c}101.66^{* * *} \\
-1,794.05 \\
11.14^{* * *}\end{array}$ & $\begin{array}{c}98.44^{* * *} \\
-1,795.66 \\
7.92^{* *}\end{array}$ & $\begin{array}{c}110.00^{* * *} \\
-1,789.88 \\
19.48^{* * *}\end{array}$ \\
\hline
\end{tabular}

Notes. Cell entries for year fixed effects denote the chi-square values testing joint significance. $N=1,107 ;{ }^{\dagger} p<0.10 ;{ }^{*} p<0.05,{ }^{* *} p<0.01$, *** $p<0.001$.

were involved in high-tech industries. We also noted some interesting correlations among the theoretical variables. First, the equity alliance variable is positively related to growth option value as well as to pre-IPO alliances $(p<0.001)$, suggesting that, everything else being equal, IPO firms with a higher growth potion value and more pre-IPO alliances are more likely to form equity alliances after the IPO. Second, the three interaction variables-pre-IPO alliances, investment bank reputation, and media coverage-are all positively related to one another $(p<0.001)$. Interestingly, IPO firms with high growth option values are not those that tend to be taken public by the most prominent underwriters, nor do they receive the most media coverage. This may be because larger firms attract the services of the most reputable underwriters and receive more media coverage (both $p<0.001$ ), yet larger firms tend to have lower growth option values in general $(p<0.001)$. As would be expected, the firms with the highest growth option values are those associated with venture capitalists and those residing in high-tech industries (both $p<0.001$ ).

Table 2 reports the results of the event history analysis conducted to examine how growth option value and the contingencies we theorized shape the likelihood of equity alliances for IPO firms. Model I is the baseline specification comprising all the control variables. Model II augments Model I by adding the direct effect of growth option value, as well as the direct effects of the three moderators: pre-IPO alliances, investment bank reputation, and media coverage. A likelihood ratio test comparing the two models indicates that these variables are jointly significant $\left(\chi^{2}=33.84, p<0.001\right)$. Models III-V introduce the three interaction terms successively, and Model VI is the full model testing all of the hypothe- 
ses at once. All six models are highly significant $(p<$ 0.001). Compared to Model II, Models III-VI all exhibit significant increases in explanatory power, as evidenced by the $\chi^{2}$ statistics.

Hypothesis 1 tests a core prediction from real options theory that firms use equity alliances to access growth options residing in other firms, or IPO firms in our study. In Table 2, the coefficient estimate for the variable growth option value is positive and highly significant in all five models $(p<0.001)$, providing strong support for the baseline prediction offered by Hypothesis 1 . This result indicates that an IPO firm with greater growth option value is more attractive as a minority investment partner than other newly public firms, as evidenced by the formation of the equity alliance.

Hypotheses 2-4 propose three contingencies that are theorized to moderate the effect of growth option value on equity alliances. Hypothesis 2 predicts that pre-IPO alliances can make IPO firms with greater growth option value become more likely objects of equity alliances. The interaction between growth option value and the pre-IPO alliances variable is positive and significant in Models III and VI ( $p<0.01$ and $p<0.05$, respectively), so there is support for Hypothesis 2.

We also sought to interpret the interaction effect. For purposes of exposition, we followed previous studies and used one standard deviation below and above the mean for the moderator variable to compare the likelihood for the theoretical variable of interest (c.f., Morita et al. 1993). This comparison indicated that when the number of pre-IPO alliances is high (i.e., one standard deviation above the mean), the effect of the IPO firm's growth option value on equity alliance likelihood is 5.4 times as large as it is when the number of pre-IPO alliances is low (i.e., one standard deviation below the mean).

Hypothesis 3 proposes that the positive effects of valuable growth options on IPO firms' likelihood of obtaining an equity partnership will be magnified for IPO firms taken public by more prominent underwriters. The positive and significant interaction of growth option value and investment bank reputation in Models IV and VI provides support for Hypothesis $3(p<0.001$ and $p<0.01$, respectively). In this case, when investment bank reputation is high, the effect of the IPO firm's growth option value on alliance likelihood is 1.7 times as large as it is when investment bank reputation is low.

Finally, Hypothesis 4 predicts that media coverage will strengthen the positive relationship between an IPO firm's growth option value and the likelihood of an equity alliance. In Models V and VI, the interaction of growth option value and media coverage is positive and significant ( $p<0.01$ and $p<0.05$, respectively), consistent with this hypothesis. Specifically, when media mentions are high, the effect of the IPO firm's growth option value on alliance likelihood is 2.7 times as large as it is when media mentions are low. Taken together, the set of results is consistent with the theory that enhanced visibility through different mechanisms enhances the relationship between valuable growth options and the likelihood of equity alliances.

We also observed some noteworthy patterns of results for the main effects and the control variables. Among the three moderator variables, only the pre-IPO alliances variable has a significant main effect $(p<0.001)$. These results suggest that the other two variables-i.e., investment bank reputation and media coverage-only play the role of moderators in affecting the likelihood of equity alliances. This finding suggests that visibility per se in the absence of valuable growth options may not be sufficient to draw in alliance investors and drive the formation of equity alliances. The positive main effect of pre-IPO alliances might reflect the development of interorganizational networks, repetitive momentum in firms' alliance activities, or collaborative capabilities (e.g., Gulati and Gargiulo 1999). It is also interesting that some of the control variables, such as firm growth and liquidity, which have been used to predict the likelihood of mergers and acquisitions post-IPO (e.g., Field and Karpoff 2002), have no bearing on minority equity investments in IPO firms. Finally, year fixed effects are jointly significant in all the models, indicating the relevance of economy-wide factors in affecting the formation of equity alliances.

\section{Supplementary Analyses}

Although the literature suggests that minority equity alliances are the preferred vehicle to access external growth opportunities, we also sought to test whether this suggestion is consistent with our data. Toward this end, we implemented separate logit models to investigate whether minority equity alliances are preferred to full acquisitions and whether they are preferred to full and majority acquisitions, when the IPO firm has valuable growth options. To conduct these tests, we focused on deals that were concluded within three years after the IPO year, resulting in 244 minority acquisitions, 209 full acquisitions, and 23 majority acquisitions. In both models, we found that the IPO firm's growth option value is positively and significantly related to the preference for minority alliance $(\beta=0.78$, std. error $=0.29, p<0.01$; $\beta=0.66$, std. error $=0.28, p<0.05)$. As another check, we also focused on deals that were concluded within five years after the IPO year. Using this time window resulted in 281 minority acquisitions, 302 full acquisitions, and 26 majority acquisitions, providing higher degrees of freedom. In analyzing this sample, we found that the results for the Growth Option Value variable are also positive and significant $(\beta=0.94$, std. error $=0.26$, $p<0.001 ; \beta=0.70$, std. error $=0.24, p<0.01)$. These additional results indicated that minority alliances are preferred to majority or full acquisitions as a means of accessing valuable growth options, which is consistent 
with prior theoretical and empirical work on real options theory and equity alliances.

We also set out to investigate some potential alternative explanations to the results we reported. First, there might be a concern that potential endogeneity may affect the interpretation of our results. For example, it can be argued that the choice of underwriters and the undertaking of publicity activities may be outcomes of some unobserved heterogeneity. We believe that endogeneity may be a lesser concern in our study, because there is not likely to be a feedback relationship between investment bank reputation (or media coverage) and the timing of a minority equity alliance. This is because IPO firms primarily seek prominent banks' support for going public, rather than attracting a minority investment following the IPO per se. As a result, endogeneity is more likely to be problematic for other dependent variables such as the timing to IPO or IPO performance. Nevertheless, we sought to address this potential concern by implementing a two-stage model controlling for self-selection, to test whether the results might be subject to endogeneity bias arising from investment bank reputation and media coverage. We found that the results were qualitatively similar to those reported in Table 2, and that endogeneity was not a concern (results available from the authors).

A second potential concern relates to the interpretation of the results for the Pre-IPO Alliances variable. It is possible that familiarity between the IPO firm and the minority investor, rather than the visibility theme that is central to our theory, might accommodate our findings. To address this possibility, we examined whether the IPO firm and the investing firm had formed alliances with each other prior to the IPO, as opposed to alliances with other organizations. We went through the names of the partners of all of the pre-IPO alliances in our data set and found that only $2 \%$ of the minority investments were preceded by one (or more) alliance(s) between the investing firm and the IPO firm specifically. This makes it unlikely that familiarity rather than visibility accounts for these results. Moreover, we re-estimated the models by excluding such alliances in the count measure of pre-IPO alliances and found that the interaction between Growth Option Value and Pre-IPO Alliances was almost the same as that reported in Table 2, suggesting that we could rule out familiarity as an alternative explanation. Another consideration is that in certain high-tech industries, firms might invest in multiple equity alliances, attempting to establish or enforce a common standard, and therefore the findings for the Pre-IPO Alliances variable might be sector specific. To address this possibility, we formally tested whether the direct and interaction effects for the Pre-IPO Alliances and Growth Option Value variables differed across high-tech and non-hightech industries, and the chi-square statistic suggested that there was no significant difference (i.e., $\chi^{2}=3.13$, n.s.).
Finally, we also implemented some additional control variables in the specification. For instance, we included a set of industry dummy variables rather than the hightech industry indicator to capture other industry-level heterogeneity that might further affect equity alliances. We found that industry fixed effects were jointly significant $(p<0.01)$, whereas the other results reported were not affected. We also considered including additional controls for other macroeconomic factors over time that might affect the features of IPOs or the incidence of equity alliances. For this reason, we included another variable, IPO Volume, defined as the total number of IPOs in the year when the focal firm went public. Data for this variable were provided by Ibbotson et al. (1994), who also maintain updated data. In separate analyses, we found that this variable was nonsignificant and that the overall results were qualitatively similar.

\section{Discussion}

\section{Contributions and Implications}

Our study offers several important implications for theory and research. First, our study responds to calls to devote attention to how firms actually discover opportunities for organizational growth (e.g., Shane and Venkatraman 2000, Bhardwaj et al. 2006). Existing research has identified cognitive inertia and established mental models as factors limiting organizations' abilities to reinvigorate their strategies (e.g., Huff et al. 1992, Barr et al. 1992), and our study complements this research by examining some of the structural factors that may affect firms' discovery of new growth opportunities. Consistent with previous real options research indicating that firms often face difficulties in recognizing latent, "shadow" options internal to the firm (Kogut 1985, Bowman and Hurry 1993), we suggest that certain challenges and information costs can also be associated with the process of discovering new growth opportunities externally. In light of these obstacles, external stimuli arising from increased visibility of the IPO firm can facilitate investors' discovery of new growth opportunities and channel their alliance activities to these opportunities. Our empirical evidence shows that firms are more likely to enter into equity alliances with IPO firms possessing more valuable growth opportunities, and this relationship is magnified for IPO firms that have obtained more visibility, either through various interorganizational relationships or via the media.

Second, our study is among the first to study empirically some of the implementation issues related to real options (c.f., Bowman and Moskowitz 2001). Recent research has examined the challenges surrounding firms' decisions to maintain or abandon growth options following option creation (e.g., Adner and Levinthal 2004, McGrath et al. 2006, Coff and Laverty 2007), and our study complements this work by highlighting some of 
the challenges surrounding firms' initial search and discovery of growth options. Although internal challenges and external market frictions exist generally, research also points to firm heterogeneity in identifying real options and managing them subsequently (e.g., Kogut 1985, Bowman and Hurry 1993), so ample opportunities likely exist for firms to capture unique value from equity alliances and the pursuit of new growth opportunities. At a broader level, attending to the various implementation challenges associated with real options can help translate and adapt concepts from financial economics into the domain of strategic management (see Bowman and Hurry 1993, Kogut and Kulatilaka 2004).

Third, our study offers a new empirical strategy to test real options theory predictions, and this approach complements existing techniques in the literature. Extant real options research has linked firms' decisions on alliance formation or termination, or other types of investments, to uncertainty as one of the key parameters in option valuation models (e.g., Kogut 1991, Folta 1998, Folta and Miller 2002). By contrast, our approach directly calculates the value of growth options. That enables researchers to examine both the antecedents of growth option value as well as how growth options can affect firms' investment decisions. Although the attractiveness of using equity alliances to access new and uncertain growth opportunities has been well recognized since Kogut's (1991) seminal work, there has been limited empirical research that directly tests this proposition. Furthermore, little research exists that has examined the challenges firms face in discovering new growth opportunities or the factors that can help channel firms' alliance activities to these opportunities.

Finally, our research also contributes to theory on strategic alliances in two respects. First, most alliance studies take exchange partners as given for analytical convenience, and the literature has paid little attention to the search for alliance partners or the discovery of collaboration opportunities. At a broad level, our study responds to recent calls to devote more research attention to the processes associated with the formation of strategic alliances (e.g., Gulati and Gargiulo 1999, Ring et al. 2005). Our arguments and findings suggest that the combination of intrinsic attributes (e.g., valuable growth opportunities) and external stimuli (e.g., visibility) make a firm more likely to attract equity alliance partners. However, visibility per se does not necessarily draw in investors, and investors may also pass up equity alliances with IPO firms that possess valuable growth opportunities but lack visibility. Second, our study complements research that has examined how alliances affect the timing and success of IPOs (e.g., Stuart et al. 1999, Gulati and Higgins 2003, Chang 2004) by demonstrating how features of IPOs have ramifications for firms' subsequent alliance activities.

\section{Limitations and Future Research Directions}

Like all studies, this one has some limitations that future research might address. We focused on IPO firms as targets of equity alliances to exploit particular features of the IPO context and the information that is released during this event. Our theoretical arguments and empirical approach, however, need not be restricted to the IPO context; extensions might consider equity partnerships between other types of companies and in other organizational settings. Extensions might also explore other activities or events (e.g., spin-offs, equity carveouts, etc.) that can enhance businesses' visibility. Future research might focus specifically on certain industries or markets that present particular obstacles for companies to locate and also access valuable growth opportunities through equity alliances. For example, an extension can be made to the international business context where geographic, cultural, and other institutional barriers can further increase the search costs of companies looking to obtain growth opportunities.

Our theory focused on different factors that can influence alliance partners' visibility, but we were not able to measure directly the underlying search processes or information costs. One of the challenges of examining companies' search for alliance partners is that there are many potential investors in IPO firms, yet data are not available for all of them, in particular for those that could have invested but ultimately did not. We have used secondary data to study factors enhancing the visibility of the investee, but future research could use survey methods to measure the search costs borne by the investor and study how such costs affect the formation of alliances. Such studies would also find it valuable to examine the degree to which the investee actively sought minority investment from the investor, or whether search was done primarily on the investor side. Extensions to this study could also incorporate the role of additional information diffusion channels such as family ties, personal networks, etc. In addition, our analyses of firms' discovery of growth opportunities are not able to empirically disentangle deliberate search from serendipity. It is possible that some firms search intensively for alliance partners (e.g., Zajac and Olsen 1993, Ring et al. 2005), whereas other firms might form equity alliances based on chance encounters or coincidental information. Field research or survey methods could help distinguish the two processes and directly investigate firms' collaboration motives as well as the means they employ to discover new growth opportunities.

Finally, it would be useful to examine the specific performance outcomes for the investor caused by the equity partnership with the IPO firm. In our study, we found that $14 \%$ of investing firms expanded their ownership position in the equity alliance, and $4 \%$ bought out the IPO firm. These percentages appear somewhat higher than those reported in related settings. For instance, 
recent research has shown that corporate venture capital investors subsequently acquire a portfolio company in fewer than 1\% of the cases (Maula and Murray 2008), and that R\&D alliances lead to acquisitions $2.6 \%$ of the time (Hagedoorn and Sadowski 1999). However, one must not just interpret subsequent acquisitions in terms of performance, because performance outcomes associated with real options are better determined at the firm or portfolio level than at the transaction level, and investing firms can derive benefits from equity alliances in many other ways, even if these alliances are not later acquired or may be individually considered a "failure" (McGrath 1999, McGrath et al. 2006). For some of these reasons, field research would be particularly valuable to examine the performance outcomes of partnerships in a finer-grained fashion and to investigate the difficulties surrounding firms' initial search for, and subsequent management of, new growth opportunities.

\section{Conclusion}

Existing research has examined firms' investment in internal ventures with embedded growth options and how they subsequently manage the ventures to achieve organizational growth. In contrast, our study investigates the challenges surrounding firms' discovery of external growth options, and our focus is on firms' option creation decisions. In particular, because of the presence of search costs, we suggest and find that external stimuli enhancing IPO firms' visibility can help facilitate investors' discovery of new growth opportunities and direct their alliances to these opportunities. Our study contributes to existing research on real options and alliances by delving into the process of firms' discovery and pursuit of growth opportunities. It also complements the focus of previous research on firms' cognitive inertia and established mental models as factors limiting organizational growth by examining external factors that may affect firms' discovery of new growth opportunities.

\section{Acknowledgments}

In developing this research, the authors have benefited from helpful discussions with Ilya Cuypers, Ha Hoang, Jing Li, and Xavier Martin, as well as from the insightful suggestions of the anonymous reviewers.

\section{References}

Adner, R., D. Levinthal. 2004. What is not a real option: Considering boundaries for the application of real options to business strategy. Acad. Management Rev. 29 74-85.

Alessandri, T. M., D. M. Lander, R. A. Bettis. 2007. Strategic implications of valuation: Evidence from valuing growth options. $A d v$. Strategic Management 24 473-499.

Allen, F., G. R. Faulhaber. 1989. Signaling by underpricing in the IPO market. J. Financial Econom. 23 303-323.

Allison, P. A. 1995. Survival Analysis Using the SAS System. SAS Institute Inc., Cary, NC.
Amram, M., N. Kulatilaka. 1999. Real Options: Managing Strategic Investment in an Uncertain World. Harvard Business School Press, Boston.

Ariño, A., J. de la Torre. 1998. Learning from failure: Towards an evolutionary model of collaborative ventures. Organ. Sci. 9 306-325.

Arrow, K. J. 1974. The Limits of Organization. W. W. Norton, New York.

Balakrishnan, S., M. P. Koza. 1993. Information asymmetry, adverse selection, and joint ventures. J. Econom. Behav. Organ. 20 99-117.

Barkema, H. G., O. Shenkar, F. Vermeulen, J. H. J. Bell. 1997. Working abroad, working with others: How firms learn to operate international joint ventures. Acad. Management J. 40 426-442.

Barnett, M. L. 2008. An attention-based view of real options reasoning. Acad. Management Rev. 33 606-628.

Barr, P. S., J. L. Stimpert, A. S. Huff. 1992. Cognitive change, strategic action, and organizational renewal. Strategic Management J. 13 15-36.

Bhardwaj, G., J. Camillus, D. A. Hounshell. 2006. Continual corporate entrepreneurial search for long-term growth. Management Sci. 52 248-261.

Blowers, S. C., P. H. Griffith, T. L. Milan. 1999. The Ernst and Young LLP Guide to the IPO Value Journey. John Wiley, New York.

Bower, J. 1970. Managing the Resource Allocation Process: A Study of Corporate Planning and Investment. Harvard Business School Press, Boston.

Bowman, E. H., D. Hurry. 1993. Strategy through the options lens: An integrated view of resource investments and the incrementalchoice process. Acad. Management Rev. 18 760-782.

Bowman, E. H., G. T. Moskowitz. 2001. Real options analysis and strategic decision making. Organ. Sci. 12 772-779.

Brau, J. C., S. E. Fawcett. 2006. Initial public offerings: An analysis of theory and practice. J. Finance 61 399-436.

Brealey, R. A., S. C. Myers. 2000. Principles of Corporate Finance, 6th ed. Irwin/McGraw-Hill, Boston.

Busby, J. S., C. G. C. Pitts. 1997. Real options in practice: An exploratory survey of how finance officers deal with flexibility in capital appraisal. Management Accounting Res. 8 169-186.

Carter, R., S. Manaster. 1990. Initial public offerings and underwriter reputation. J. Finance 45 1045-1067.

Casella, A., N. Hanaki. 2006. Why personal ties cannot be bought. Amer. Econom. Rev. 96 261-264.

Chang, S.-J. 2004. Venture capital financing, strategic alliances, and the initial public offerings of internet startups. J. Bus. Venturing 19 721-741.

Chi, T. 2000. Option to acquire or divest a joint venture. Strategic Management J. 21 665-687.

Chi, T., D. J. McGuire. 1996. Collaborative ventures and value of learning: Integrating the transaction cost and strategic option perspectives on foreign market entry. J. Internat. Bus. Stud. 27 285-308.

Chung, K. H., M. Li, L. Yu. 2005. Assets in place, growth opportunities, and IPO returns. Financial Management 34 65-88.

Coff, R., K. Laverty. 2007. Real options meet organization theory: Coping with path dependencies, agency costs, and organizational form. Adv. Strategic Management 24 343-372.

Corwin, S. A., J. H. Harris. 2001. The initial listing decisions of firms that go public. Financial Management 30 35-55. 
Cox, D. 1972. Regression models and life tables. J. Roy. Statist. Soc., Ser. B 34 187-220.

Cox, D., D. Oakes. 1984. Analysis of Survival Data. Chapman and Hall, London.

Demers, E., K. Lewellen. 2003. The marketing role of IPOs: Evidence from Internet stocks. J. Financial Econom. 68 413-437.

Dhanaraj, C., M. A. Lyles, H. K. Steensma, L. Tihanyi. 2004. Managing tacit and explicit knowledge transfer in IJVs: The role of relational embeddedness and the impact on performance. J. Internat. Bus. Stud. 35 428-442.

Dussauge, P., B. Garrette, W. Mitchell. 2000. Learning from competing partners: Outcomes and durations of scale and link alliances in Europe, North America, and Asia. Strategic Management J. 21 99-126.

Dyer, J. H., H. Singh. 1998. The relational view: Cooperative strategy and sources of interorganizational competitive advantage. Acad. Management Rev. 23 660-679.

Field, L. C., J. M. Karpoff. 2002. Takeover defenses of IPO firms. J. Finance 57 1857-1889.

Folta, T. B. 1998. Governance and uncertainty: The tradeoff between administrative control and commitment. Strategic Management J. 19 1007-1028.

Folta, T. B., K. D. Miller. 2002. Real options and equity partnerships. Strategic Management J. 23 77-88.

Gulati, R. 1995. Social structure and alliance formation patterns: A longitudinal analysis. Admin. Sci. Quart. 40 619-652.

Gulati, R., M. Gargiulo. 1999. Where do interorganizational networks come from? Amer. J. Sociol. 105 177-231.

Gulati, R., M. C. Higgins. 2003. Which ties matter when? The contingent effects of interorganizational partnerships on IPO success. Strategic Management J. 24 127-144.

Hagedoorn, J. 1993. Understanding the rationale of strategic technology partnering. Strategic Management J. 14 371-386.

Hagedoorn, J., B. Sadowski. 1999. The transition from strategic technology alliances to mergers and acquisitions: An exploratory study. J. Management Stud. 36 87-107.

Hayek, F. A. 1945. The use of knowledge in society. Amer. Econom. Rev. 35 519-530.

Hennart, J.-F., S. Reddy. 1997. The choice between mergers/acquisitions and joint ventures: The case of Japanese investors in the United States. Strategic Management J. 18 1-12.

Higgins, M. C., R. Gulati. 2003. Getting off to a good start: The effects of upper echelon affiliations on underwriter prestige. Organ. Sci. 14 244-263.

Higgins, M. C., R. Gulati. 2006. Stacking the deck: The effects of top management backgrounds on investor decisions. Strategic Management J. 27 1-25.

Hitt, M. A., D. Alhstrom, M. T. Dacin, E. Levitas, L. Svobodina. 2004. The institutional effects on strategic alliance partner selection in transition economies: China versus Russia. Organ. Sci. 15 1731-85.

Howell, S. D., A. J. Jagle. 1997. Laboratory evidence on how managers intuitively value real growth options. J. Bus. Finance Accounting 24 915-935.

Huff, J. O., A. S. Huff, H. Thomas. 1992. Strategic renewal and the interaction of cumulative stress and inertia. Strategic Management J. 13 55-75.

Huston, L., N. Sakkab. 2006. Connect and develop: Inside Procter and Gamble's new model for innovation. Harvard Bus. Rev. 84 $58-63$.
Ibbotson, R., J. Sindelar, J. Ritter. 1994. The market's problem with the pricing of initial public offerings. J. Appl. Corporate Finance 7 66-74.

Inkpen, A., P. W. Beamish. 1997. Knowledge, bargaining power, and the instability of international joint ventures. Acad. Management Rev. 22 177-202.

Jensen, M. 2004. Who gets Wall Street's attention? How alliance announcements and alliance density affect analyst coverage. Strategic Organ. 2 293-312.

Kesner, I. F., D. L. Shapiro, A. Sharma. 1994. Brokering mergers: An agency theory perspective on the role of representatives. Acad. Management J. 37 703-721.

Kester, W. C. 1984. Today's options for tomorrow's growth. Harvard Bus. Rev. 62(2) 153-160.

Knight, F. H. 1921. Risk, Uncertainty, and Profit. Hart, Schaffner, \& Marx, Boston

Kogut, B. 1985. Designing global strategies: Profiting from operational flexibility. Sloan Management Rev. 27(1) 27-38.

Kogut, B. 1991. Joint ventures and the option to expand and acquire. Management Sci. 37 19-33.

Kogut, B., N. Kulatilaka. 1994. Options thinking and platform investments: Investing in opportunity. California Management Rev. 36 $52-71$.

Kogut, B., N. Kulatilaka. 2004. Real options pricing and organizations: The contingent risks of extended theoretical domains. Acad. Management Rev. 29 102-110.

Koh, J., N. Venkatraman. 1991. Joint venture formations and stock market reactions: An assessment of the information technology sector. Acad. Management J. 34 869-892.

Koza, M., A. Lewin. 1998. The co-evolution of strategic alliances. Organ. Sci. 9 255-264.

Lander, D. M., G. E. Pinches. 1998. Challenges to the practical implementation of modeling and valuing real options. Quart. Rev. Econom. Finance 38 537-567.

Lin, D., L. Wei. 1989. The robust inference for the Cox proportional hazards model. J. Amer. Statist. Assoc. 84 1074-1078.

Long, M. S., J. Ward, J. Zhang. 2005. A cross-sectional analysis of firm growth options. L. Trigeorgis, ed. Innovation, Organization and Strategy: New Developments and Applications in Real Options. Oxford University Press, Cambridge.

Loughran, T., J. Ritter. 2004. Why has IPO underpricing changed over time? Financial Management 33 5-37.

Maula, M., G. Murray. 2008. Corporate venture capital and the exercise of the options to acquire. Working paper, Helsinki University of Technology and London Business School, London.

McGrath, R. G. 1997. A real options logic for initiating technology positioning investments. Acad. Management Rev. 22 974-996.

McGrath, R. G. 1999. Falling forward: Real options reasoning and entrepreneurial failure. Acad. Management Rev. 24 13-30.

McGrath, R. G., A. Nerkar. 2004. Real options reasoning and a new look at the R\&D investment strategies of pharmaceutical firms. Strategic Management J. 25 1-21.

McGrath, R. G., T. Keil, T. Tukiainen. 2006. Extracting value from corporate venturing. Sloan Management Rev. 48 50-56.

Megginson, W., K. Weiss. 1991. Venture capitalist certification of initial public offerings. J. Finance 46 879-903.

Miller, M. H., F. Modigliani. 1961. Dividend policy, growth and the valuation of shares. J. Bus. 34 411-433. 
Mitchell, W., K. Singh. 1992. Incumbents' use of pre-entry alliances before expansion into new technical subfields of an industry. J. Econom. Behav. Organ. 18 347-372.

Mitchell, W., K. Singh. 1996. Survival of businesses using collaborative relationships to commercialize complex goods. Strategic Management J. 17 169-195.

Morita, J. G., T. W. Lee, R. T. Mowday. 1993. The regression-analog to survival analysis: A selected application to turnover research. Acad. Management J. 36 1430-1464.

Mowery, D. C., J. E. Oxley, B. S. Silverman. 1996. Strategic alliances and interfirm knowledge transfer. Strategic Management J. 17 77-92.

Myers, S. C. 1977. Determinants of corporate borrowing. J. Financial Econom. 5 147-175.

Parkhe, A. 1993. Strategic alliance structuring: A game theoretic and transaction costs examination of interfirm cooperation. Acad. Management J. 36 794-829.

Pindyck, R. S. 1988. Irreversible investment, capacity choice, and the value of the firm. Amer. Econom. Rev. 78 969-985.

Pisano, G. P. 1989. Using equity participation to support exchange: Evidence from the biotechnology industry. J. Law, Econom., Organ. 5 109-126.

Pollock, T. G., V. P. Rindova. 2003. Media legitimation effects in the market for initial public offerings. Acad. Management J. 46 631-642.

Rangan, S. 2000. The problem of search and deliberation in economic action: When social networks really matter. Acad. Management Rev. 25 813-838.

Ravasi, D., G. Marchisio. 2003. Going public and the enrichment of a supportive network. Small Bus. Econom. 21 381-395.

Reuer, J. J., M. J. Leiblein. 2000. Downside risk implications of multinationality and international joint ventures. Acad. Management J. 43 203-214.

Ring, P. S., Y. L. Doz, P. M. Olk. 2005. Managing formation processes in R\&D consortia. California Management Rev. 47 $137-156$.
Robins, J. A., S. Tallman, K. Fladmoe-Lindquist. 2002. Autonomy and dependence of international cooperative ventures: An exploration of the strategic performance of US ventures in Mexico. Strategic Management J. 23 881-901.

Rothaermel, F. T., D. L. Deeds. 2004. Exploration and exploitation alliances in biotechnology: A system of new product development. Strategic Management J. 25 201-221.

Schwartz, E. S., M. Moon. 2000. Rational pricing of Internet companies. Financial Analysts J. 56(3) 62-75.

Shane, S., S. Venkatraman. 2000. The promise of entrepreneurship as a field of research. Acad. Management Rev. 25 217-226.

Singh, K., W. Mitchell. 2005. Growth dynamics: The bidirectional relationship between interfirm collaboration and business sales in entrant and incumbent alliances. Strategic Management J. 26 497-521.

Stewart, G. B. 1991. The Quest for Value: A Guide for Senior Managers. Harper, New York.

Stigler, G. J. 1961. The economics of information. J. Political Econom. 69 213-225.

Stuart, T. E., H. Hoang, R. C. Hybels. 1999. Interorganizational endorsements and the performance of entrepreneurial ventures. Admin. Sci. Quart. 44 315-349.

Tabachnick, B. G., L. S. Fidell. 1996. Using Multivariate Statistics, 3rd ed. Harper Collins, New York.

Titman, S., B. Trueman. 1986. Information quality and the valuation of new issues. J. Accounting Econom. 8 159-172.

Tong, T. W., J. J. Reuer. 2006. Firm and industry influences on the value of growth options. Strategic Organ. 4 71-96.

Tong, T. W., J. J. Reuer, M. W. Peng. 2008. International joint ventures and the value of growth options. Acad. Management $J$. 51(5).

Trigeorgis, L. 1996. Real Options: Managerial Flexibility and Strategy in Resource Allocation. MIT Press, Cambridge, MA.

Zajac, E. J., C. Olsen. 1993. From transaction cost to transaction value analysis: Implications for the study of interorganizational strategies. J. Management Stud. 30 131-145. 